\title{
Consumption of toxic plants by the hoatzin*
}

\section{M.G. Dominguez-Bello ${ }^{1,3}$, R.E. Aguiar², M.A. García-Amado² and F. Michelangeli²}

\author{
${ }^{1}$ Departament of Biology, University of Puerto Rico \\ San Juan, PR 00931, USA \\ ${ }^{2}$ Laboratory of Gastrointestinal Physiology, CBB, \\ Venezuelan Institute of Scientific Investigations \\ Caracas AP 2182, 1020A, Venezuela
}

\begin{abstract}
The hoatzin is a folivore bird with crop microbial fermentation. We studied plants selected by the hoatzin as food and their toxicity, in relation with non-selected plants. Toxicity of dietary and non dietary plants was tested in bioassays of ethanol plant extracts on eukaryote cells lines and on crop bacterial cultures. The hoatzin selected young leaves and soft tissues from the plants regardless their abundance or their cytotoxic activity. The most cytotoxic dietary plants were from Pithecellobium and Pterocarpus genera, and crop bacteria were less inhibited by plant extracts if the corresponding plants were consumed.
\end{abstract}

KEYWORDS: hoatzin, crop fermentation, plant toxins, cytotoxicity

\section{INTRODUCTION}

Fermentative digestion allows herbivores to exploit plants as a food resource, by microbial digestion of plant compounds that otherwise have low nutritional value or are toxic. Plant toxins have presumably evolved as defense mechanism against predation (Bell, 1981), but detoxification mechanisms have evolve to overcome these plant defenses, including foregut microbial detoxification.

Foregut fermentation is found in Artyodactyls and in few other mammals, and in only one bird, the neotropical hoatzin (Opisthocomus hoazin), of the family Opisthocomidae, and the only case of foregut fermentation among birds (Grajal et al., 1989). The aim of this study was to determine the relation between plant toxicity and dietary selection by the hoatzin.

\footnotetext{
* Supported in part by NSF, Grant IOS-0716911

${ }^{3}$ Corresponding author: e-mail: mgdbello@uprr.pr
} 


\section{MATERIAL AND METHODS}

Observations were performed at the end of the dry and of the rain period, at Central Venezuelan plains. All plants from the gallery forest inhabited by hoatzins had already been ranked by abundance (Domínguez-Bello et al., 1994).

A total of 26 extracts from 13 plant species were prepared. Fresh material $\left(1 \mathrm{~kg}\right.$ ) from each plant was obtained, dried at $40^{\circ} \mathrm{C}$ and milled before three rounds of $24 \mathrm{~h}$ maceration with ethanol $(95 \%)$ in dark bottles. The filtrates were pooled, dried in a rota-evaporator (under $40^{\circ} \mathrm{C}$ ) and kept refrigerated in dark bottles. Extracts were re-extracted with water at $25^{\circ} \mathrm{C}$ under agitation for 10 times. Water extracts were lyophilized and kept at $-70^{\circ} \mathrm{C}$ until the bioassays were performed.

Cytotoxicity on eukaryotic cell cultures was tested on four epithelial cell lines grown on Eagle's minimum essential medium (HeLa and MA104), Dubelcco's plus glucose (HT29) and RPMI-1640 (Hep2), all supplemented with bovine foetal serum (10\%). To determine inhibition of cell growth (cytostatic effect), $200 \mu 1$ of a suspension of $3 \times 106 \mathrm{cells} / \mathrm{ml}$ were placed in 96-well plates, and after $6 \mathrm{~h}$ culture medium was replaced by medium containing each extract $(500 \mu \mathrm{g} / \mathrm{ml})$. Plates were incubated $\left(37^{\circ} \mathrm{C}\right)$ in humid $\mathrm{CO}_{2}$ atmosphere for the time at which confluence was reached in the control wells $(24 \mathrm{~h}$ for MA104, and $48 \mathrm{~h}$ for the other cell lines). For cytocidal activity, extracts were added (50 to $500 \mu \mathrm{g} / \mathrm{ml}$ ) after the cells were confluent. Cell death was measured after $5 \mathrm{~h}$ incubation by ethidium bromide fluorescence. Maximum cell death was determined by adding digitonin $(100 \mu \mathrm{g} / \mathrm{ml})$. All assays were performed twice with 3 replicates.

Activity of plant extracts on bacterial growth was determined in crop primary and plant extracts-enriched cultures. Enrichment cultures were primary cultures grown on medium containing the extract, and transferred to fresh media every 6-8 weeks. Crop cultures were grown anaerobically using Hungate tubes (under $\mathrm{CO}_{2}$ ) on Brain-Heart infusion medium (BBL). Growth was recorded spectrophotometrically (OD $600 \mathrm{~nm}$, in a Spectronic 20D), until stationary phase was reached. Assays were done twice with three replicates. Extract activity was also tested on S. aureus and E. coli as controls.

\section{RESULTS}

The hoatzin selected mainly young leaves and shoots, and the preferred plants both in the rain and dry period were from the legume families Mimosaceae and Papilionaceae (Table 1). 
Table 1. Plants sampled for toxicity assays and their consumption by the hoatzin

\begin{tabular}{|c|c|c|c|c|c|}
\hline Plant species & Family & $\begin{array}{c}\text { Abundance } \\
\text { rank }^{1}\end{array}$ & $\begin{array}{l}\text { Extract } \\
\text { code }\end{array}$ & $\begin{array}{c}\text { Sampled plant } \\
\text { part }\end{array}$ & $\begin{array}{c}\text { Plant part } \\
\text { consumed }^{2}\end{array}$ \\
\hline \multirow{2}{*}{ Coccoloba caracasana } & \multirow{2}{*}{ Polygonaceae } & \multirow[t]{2}{*}{1} & $\mathrm{j}$ & flowers & + \\
\hline & & & d & mature leaves & - \\
\hline \multirow{2}{*}{ Lecythis ollaria } & \multirow[t]{2}{*}{ Lecythidaceae } & \multirow[t]{2}{*}{2} & g & young leaves & - \\
\hline & & & $\mathrm{h}$ & mature leaves & - \\
\hline \multirow{2}{*}{ Derris moniliformis } & \multirow[t]{2}{*}{ Papilionaceae } & \multirow[t]{2}{*}{3} & $\mathrm{~m}$ & young leaves & ++ \\
\hline & & & $\mathrm{k}$ & mature leaves & - \\
\hline \multirow[t]{2}{*}{ Dugetia riberensis } & Annonaceae & 9 & $\mathrm{u}$ & young leaves & + \\
\hline & \multirow[t]{4}{*}{ Sterculiaceae } & \multirow[t]{4}{*}{5} & o & shoots & ++ \\
\hline \multirow{3}{*}{ Guazuma tomentosa } & & & $\mathrm{t}$ & flowers & ++ \\
\hline & & & $\mathrm{n}$ & mature leaves & + \\
\hline & & & $\mathrm{r}$ & senescent leaves & - \\
\hline \multirow{3}{*}{$\begin{array}{l}\text { Pterocarpus } \\
\quad \text { acapulcensis }\end{array}$} & \multirow[t]{3}{*}{ Papilionaceae } & \multirow[t]{3}{*}{10} & $\mathrm{e}$ & flowers & + \\
\hline & & & $\mathrm{f}$ & young leaves & ++ \\
\hline & & & $\mathrm{v}$ & mature leaves & - \\
\hline \multirow{2}{*}{ Pithecellobium dulce } & \multirow[t]{2}{*}{ Mimosaceae } & \multirow[t]{2}{*}{12} & $\mathrm{a}$ & young leaves & ++ \\
\hline & & & $\mathrm{c}$ & mature leaves & - \\
\hline \multirow{2}{*}{$\begin{array}{l}\text { Pithecellobium } \\
\text { pistaciaefolium }\end{array}$} & \multirow[t]{2}{*}{ Mimosaceae } & \multirow[t]{2}{*}{37} & $\mathrm{~b}$ & shoots & ++ \\
\hline & & & $\mathrm{i}$ & mature leaves & - \\
\hline Ruprechtia ramiflora & Polygonaceae & 16 & 1 & mature leaves & - \\
\hline \multirow{2}{*}{ Pithecellobium tortum } & \multirow[t]{2}{*}{ Mimosaceae } & \multirow[t]{2}{*}{8} & $\mathrm{~s}$ & young leaves & ++ \\
\hline & & & $\mathrm{x}$ & mature leaves & + \\
\hline Sarcostemma glaucum & Asclepiadaceae & 49 & $\mathrm{w}$ & whole plant & + \\
\hline \multirow{2}{*}{$\begin{array}{l}\text { Machaerium } \\
\text { caicarense }\end{array}$} & \multirow[t]{2}{*}{ Papilionaceae } & & $\mathrm{z}$ & young leaves & ++ \\
\hline & & & $\mathrm{p}$ & mature leaves & - \\
\hline
\end{tabular}

${ }^{1}$ plant abundance rank based on Dominguez-Bello et al. (1994)

${ }^{2}$ dietary consumption: ++ frequently consumed, +consumed, - not consumed

In addition, shoots and flowers of Guazuma tomentosa were also consumed at the start of the rain period. Towards the end of the rain period, young leaves from Pithecellobium dulce and mature leaves from Acacia glomerosa and Pithecellobium tortum were the main choice for the hoatzins.

The effect of plant extracts on cell lines growth is shown in Figure 1. In general, extracts from young leaves were more inhibitory than other plant parts (mature leaves, flowers). Highly inhibitory extracts to all cell lines were Fabaceae species - Pithecellobium dulce $(\mathrm{a}, \mathrm{c})$, Pithecellobium pistaciaefolium (b, i) and Pterocarpus acapulcensis (f, e). 
MA 104

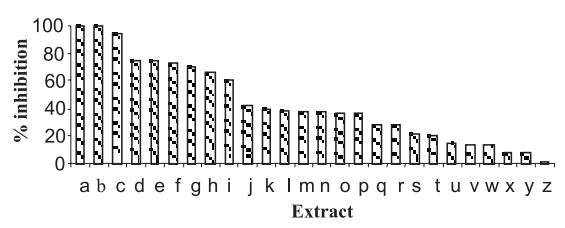

HELA

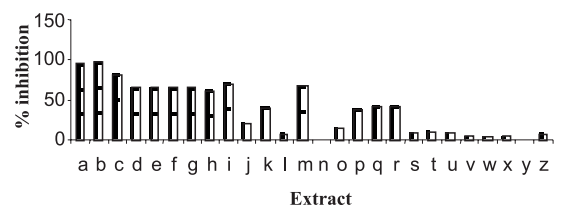

HT 29

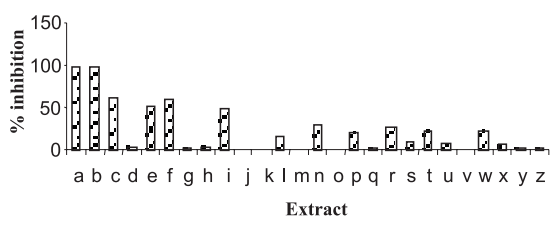

HEP 2

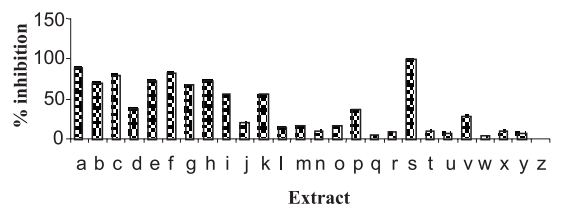

Figure 1. Inhibition of four different eukaryotic cell growth by plant extracts $(500 \mu \mathrm{g} / \mathrm{ml})$; a to $\mathrm{z}$ in $\times$ axis, as described in Table 1 . The ranking from a to $\mathrm{z}$ corresponds to decreasing toxicity to MA104 cells

Shoots of Pithecellobium pistaciaefolium (b) inhibited growth of S. aureus and E. coli in more than $85 \%$. Extracts from plants being consumed by the hoatzin, had little effect on primary crop cultures and plant extract-enriched cultures showed improved growth in the presence of extracts. When tested on primary cultures from the crop of a hoatzin not consuming the plants, all extracts but P. tortum (s) had an inhibitory effect (Figure 2).

Pithecellobium dulce (a)

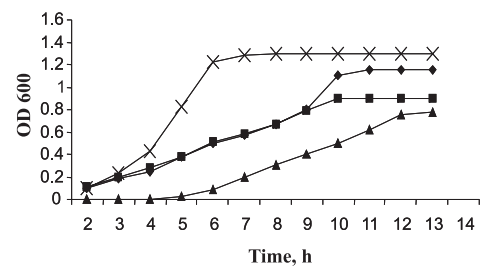

Pithecellobium tortum (s)

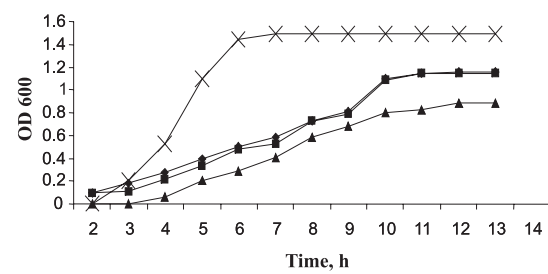

Pterocarpus acapulcensis (f)

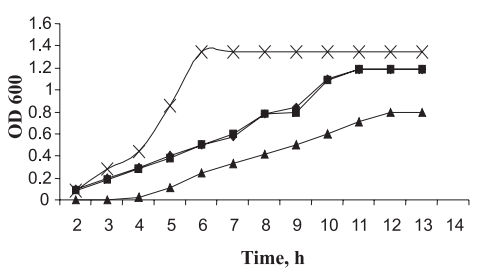

Pithecellobium (b)

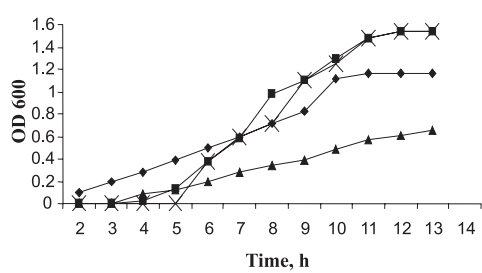

Figure 2. Growth of crop bacteria from a hoatzin consuming Pithecellobium species. Primary cultures with or without plant extracts (squares and diamonds, respectively) and enrichment cultures with or without plant extracts (crosses and triangles, respectively) 


\section{CONCLUSIONS}

As other small herbivores, the hoatzin is a concentrate selector, choosing mostly young leaves and shoots, regardless their abundance or their cytotoxic activity. Plants that were abundant but not consumed, generally had larger, coriaceus leaves with a hard epidermis, which might impair tearing and cutting by the bird. Physiological adaptations that allow the hoatzin to cope with dietary toxins are yet unknown. The lower sensitivity of crop bacteria to extracts of plants if these were consumed by the bird, suggests that toxins drive changes in the crop ecosystem towards predominance of tolerant bacteria.

\section{ACKNOWLEDGEMENTS}

We acknowledge the technical asistance of Mr Nelson Reyes in performing saponin detoxification experiments

\section{RERERENCES}

Bell E.A., 1981. The physiological roles of secondary (natural) products. In: The Biochemistry of Plants. Vol. VII. Academic Press, London

Domínguez-Bello M.G., Michelangeli F., Ruiz M.C., Garcia A., Rodriguez E., 1994. Ecology of the folivorous hoatzin (Opisthocomus hoazin) on the Venezuelan plains. The Auk 111, 643-651

Grajal A., Strahl S., Parra R., Dominguez M.G., Neher A., 1989. Foregut fermentation in the hoatzin, a neotropical leave-eating bird. Science 245, 1236-1238 